\title{
The effects of rehabilitation on intellectually-disabled people - a systematic review
}

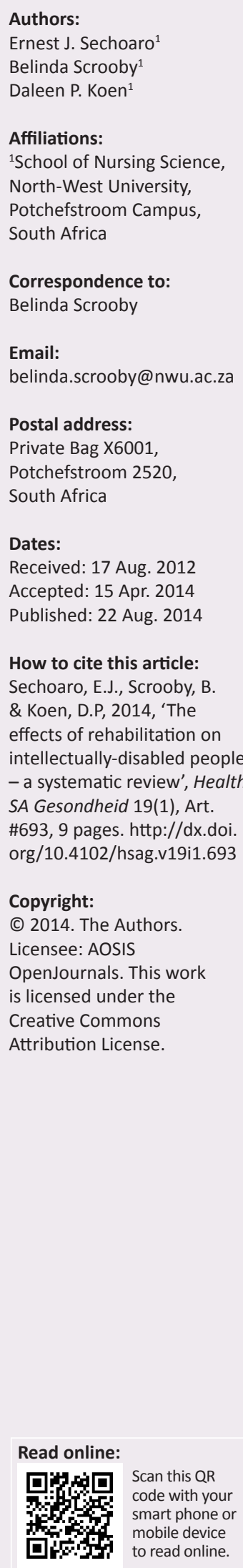

Background: Rehabilitation has emerged as a comprehensive approach to addressing intellectually-disabled peoples' skill deficits, improving competencies and facilitating optimal functioning in order to provide the greatest possible measure of social and economic participation, self-reliance and independence.

Objective: To synthesise critically and summarise the best available evidence of the effects of rehabilitation on intellectually-disabled people.

Method: Literature searches of different electronic databases and manual searches were conducted using selected keywords. Studies on the effects of rehabilitation on intellectuallydisabled people were selected systematically, appraised critically for methodological quality and summarised.

Results: Rehabilitation interventions indicated good outcomes with regard to intellectuallydisabled people. Findings showed that people with mild to moderate intellectual disabilities improved in terms of activities of daily living (ADL) after rehabilitation. Improvement was noted in ADL, self-care skills, communication skills and cognitive achievements.

Conclusion: Findings demonstrated positive rehabilitation effects on intellectually-disabled people. This study contributes to the comprehensive nursing care of intellectually-disabled people by endorsement of the effectiveness of rehabilitation in terms of ADL, self-care skills, communication skills and cognitive achievements. The collected evidence of this study may contribute to the education of more effective nurse practitioners involved in the daily care and rehabilitation of intellectually-disabled people.

Agtergrond: Rehabilitasie het ontwikkel in 'n omvattende benadering met 'n kombinasie van behandelingsmetodes om die veelvoudige hindernisse wat met intellektuele gestremdheid geassosieer word die hoof te bied. Rehabilitasie word gebruik om die intellektueel gestremde mense se vaardigheidstekorte aan te pak, bevoegdheid te bevorder en optimal funksionering te fasiliteer met die beste moontlike sosiale en ekonomiese deelname, onafhanklikheid, selfstandigheid en selfbeskikking as doelwit.

Doelstelling: Hierdie sistematiese literatuuroorsig het die beskikbare bewyse van die effek van rehabilitasie op intellektueel gestremde mense ondersoek en beskryf.

Metode: Literatuur soektogte van verskillende elektroniese databasisse en handsoektogte was gedoen deur geselekteerde sleutelwoorde te gebruik. Studies oor die effekte van rehabilitasie op die intellektueel gestremde persone was stelselmatig geselekteer, krities ontleed vir metodologiese kwaliteit en opgesom.

Resultate: Rehabilitasie-intervensies het goeie uitkomste op intellektueel gestremde mense getoon. Bevindinge het getoon dat mense met ligte tot matige intellektuele gestremdhede ten opsigte van daaglikse aktiwiteite na rehabilitasie verbeter het. Vordering is opgemerk in daaglikse leefaktiwiteite, selfsorgvaardighede, kommunikasievaardighede en kognitiewe prestasie.

Gevolgtrekkings: Bevindinge het positiewe rehabilitasie effekte op die intellektueel gestremde mense getoon. Hierdie studie dra by tot die omvattende verpleging van intellektueel gestremde mense deur ondersteuning van die doeltreffendheid van rehabilitasie met betrekking tot daaglikse leefaktiwiteite, selfsorgvaardighede, kommunikasievaardighede en kognitiewe prestasie te gee. Die bewyse wat in hierdie studie ingesamel is, kan bydra tot die opleiding van doeltreffender verpleegkundiges wat by die daaglikse versorging en rehabilitasie van intellektueel gestremde mense betrokke is.

\section{Introduction}

People with intellectual disabilities have complex needs and limitations in terms of bodily functions, personal factors and activity skills. These disabilities pose significant challenges for 
them as well as for healthcare professionals. Therefore, intellectually-disabled people require specific forms of health and special social services (Lin et al. 2006:1499). Thompson, McGrew and Bruininks (2002:25) believe that efforts can be made to improve on methods that can lead to effective interventions to increase learning and adaptation on the part of intellectually-disabled people. This systematic review synthesised and described best evidence regarding the effects of rehabilitation on intellectually-disabled people as a means of overcoming the challenges outlined.

\section{Background}

Rehabilitation has emerged as a comprehensive approach with a combination of treatment modalities that have the purpose of addressing multiple impediments and overcoming disabilities. Rehabilitation is a goal-oriented process, with the aim of enabling intellectually-disabled people to reach an optimum mental, physical and/or social functional level, thereby providing them with the tools required to change their lives (Department of Health 2000:31).

The philosophy behind rehabilitation is that rehabilitation concentrates more on prevention or reduction of impairment of handicap than on treatment of diseases. It is grounded strongly on the belief in the empowerment of intellectuallydisabled people and it identifies the individual's goals on the grounds of which a plan is developed to meet these goals. From this rehabilitation perspective, it is important to extend support as long as possible. Furthermore, this support should not be withdrawn when the client improves (Lin et al. 2006:1499-1500).

Looking at international trends and prompted by the United Nation's actions to declare the rights of intellectually-disabled people and to adopt the Declaration of the Rights of Disabled People in 1975, the Rehabilitation Act of 1973 of the United States of America (USA) prioritised the mandatory provision of rehabilitation services for people with disabilities (Lin et al. 2006:1499-1500). The South Korean government enacted the Special Education Promotion Act in 1977; this regulation and the first legal policy established promoted normalisation, mainstreaming, inclusive education, early education and individualised education, thus improving the educational opportunities for people with disabilities (Oh et al. 2005:50). The historical overview of rehabilitation from Southern Korean literature reiterates that rehabilitation started to develop only in the early 1950s. The South Korean government agreed to expand their social services to be inclusive of rehabilitation for people with disabilities (Oh et al. 2005:49). Despite progress made, the delivery of vocational rehabilitation services was still subject to many problems and limitations (Oh et al. 2005:49). In the 1960s, many medical doctors who had been trained in rehabilitation medicine and other specialties in the United States, returned to South Korea in order to help in orthopaedic and rehabilitation departments in major hospitals. Soon thereafter, resident training programmes were developed in South Korea in these specialty fields (Oh et al. 2005:50).
In South Africa, the current estimates for the proportion of the South African population with disabilities converge at $5 \%-6 \%$ of the population, which equates to around 2.5 million people with disabilities in South Africa. There is thus a need for appropriate policies and services for this sector of the population. Chappell and Johannsmeier (2009:7) further elucidated that community-based rehabilitation (CBR) developed in the late 1980s as a result of challenges faced by people with disabilities. The National Rehabilitation Policy document (Department of Health 2000:3) is in agreement with the above, facilitating the realisation of every citizen's constitutional right of access to healthcare services. This policy document forms part of South Africa's strategy to improve the quality of life of people with disabilities, serving as a vehicle to bring about equality with regard to opportunities and to enhance their human rights.

Burns (2008:46) gives an overview of the historical background of earlier South African legislation relating to the treatment of mental health care users, including people with disabilities. Burns states that the Mental Health Act 18 of 1973 (South Africa 1973) focused on the control and treatment of these patients. This Act also reinforced the separation of mental and general healthcare. Psychiatric services were isolated from and not integrated into primary healthcare. The structure of these old systems disempowered, alienated and stigmatised mentally-ill and intellectually-disabled people, with traumatic and damaging consequences. The psychiatric service provision under the Mental Health Act (South Africa 1973) was not grounded on the ethical principles of autonomy, beneficence, non-maleficence and justice, which led to human rights infringements (Burns 2008:46).

Because change was necessary, the Mental Health Care Act 17 of 2002 (South Africa 2002) was promulgated in South Africa against the backdrop of positive international developments in mental health legislation. This new culture focused on human rights. The new Mental Health Care Act reflects this new spirit and is based on the important principles of provision of care, treatment and rehabilitation. Mentallydisabled people's rights are respected, in other words their right to be provided with care, treatment and rehabilitation, with the least possible restriction of their freedom (Burns 2008:47).

In conclusion, rehabilitation enables the maximisation of a person's functional abilities and helps intellectually-disabled people learn to improve the skills needed for walking, eating or self-care management (Legere 2007:227). Martin (2006:125-126) supports the above by stating that intellectuallydisabled people must learn to make decisions for their selfcare. Without learning and applying these skills, intellectuallydisabled people would be hospitalised repeatedly because of their lack of learned skills. It is important that people with intellectual disabilities receive services and support that will enable them to live a productive and fulfilling life, whilst being protected legally from unfair treatment and exploitation. The rehabilitation of intellectually-disabled people should be applied in practice in order to enhance their functional skills and to improve their quality of life. 


\section{Problem statement}

Based on the above information, it becomes clear that the improvement of rehabilitation services to address the skills deficit for intellectually-disabled people is an ongoing challenge in the public health system. Rehabilitation is applied inconsistently and the effects thereof are not stipulated clearly. In this study, a systematic review was thus conducted in order to synthesise critically and summarise best available evidence regarding the effects of rehabilitation on intellectually-disabled people. Critical synthesis and summary of the effects of rehabilitation may guide and increase the knowledge required to meet the challenges faced by intellectually-disabled people. Because of the gap in functional skills deficits, the researcher identified the need to explore the effects of rehabilitation on intellectually-disabled people. On reflection, the major effect of rehabilitation on intellectually-disabled people may be positive client outcomes, which include improved functional skills levels, adaptation to their disability, maximised functional independence with the least amount of ongoing professional assistance and maintained biopsychosocial status for community-based living, marked by growth toward autonomy and achieving a full, rich and fulfilling life.

\section{Research method and design}

The research method followed in this study was a systematic literature review that included both national and international literature and studies that focused on and provided broad scientific evidence of the effects of rehabilitation on intellectually-disabled people (Badr 2007:79). As stated by Whittemore and Knafl (2005:547), '[s]ystematic reviews are research reviews that combine the evidence of multiple studies regarding a clinical problem to inform clinical practice'. The following five steps associated with the systematic review of reported evidence (American Dietetic Association [ADA] 2005), were used to address the study objectives:

Step 1: Formulate a focused review question

Step 2: Formulate a search strategy

Step 3: Perform a critical appraisal

Step 4: Summarise the evidence, by means of:
a. data extraction
b. data analysis

Step 5: Summarise the findings.

\section{Step 1: The review question}

The review question was structured using the following elements - Population of interest (P); Intervention (I); Comparisons (C); Outcome (O); and Time frame (T) - namely, the PICOT format (Whittemore \& Knafl 2005:548). For this study, Setting (S) was also included. The operationalisation of these elements is displayed in Table 1.

The review question was then stated as follows: 'What are the effects of rehabilitation on intellectually-disabled people?'.

\section{Step 2: Gathering and classifying the evidence}

The next step in conducting a systematic review is to gather all the relevant literature using a structured search strategy. The 'search process should be as transparent as possible and documented in a way that enables it to be evaluated and reproduced' (Centre for Reviews and Dissemination [CRD] 2009:16).

\section{Search strategy}

A comprehensive search during the systematic review was done in order to identify the maximal number of eligible primary sources and to minimise selection bias (Whittemore \& Knafl 2005:548). Searches in different electronic databases as well as manual searches of references to collect primary studies were conducted using selected keywords. The search strategy was not limited to the English language, as doing so would have introduced language bias (CRD 2009:17). Sources that were searched are displayed in Table 2.

\section{Selected study to be included}

Studies were selected by means of inclusion and exclusion criteria (Table 2). The criteria were determined in order to make certain that the boundaries of the review question are clearly defined. The aim of the search was to include all the studies relevant to the research question.

\section{Inclusion criteria}

The inclusion criteria for this study were:

- Research studies, such as systematic reviews

- Published journal articles on primary studies

- Published theses and dissertations

- Grey literature - unpublished theses and dissertations

TABLE 1: Use of the PICOT format, as applied to this study.

\begin{tabular}{ll}
\hline PICOT format & Operationalisation \\
\hline Population & Mild and moderate intellectually-disabled people. \\
Intervention & Rehabilitation. \\
Comparisons & No comparison. \\
Outcome & $\begin{array}{l}\text { Positive client outcomes, which include improved functional skills levels, adaptation to disability, maximised functional independence with the } \\
\text { least amount of ongoing professional assistance and maintained bio-psychosocial status for community-based living, marked by growth towards } \\
\text { autonomy and achieving a full, rich and fulfilling life. }\end{array}$ \\
Iime & Not applicable. \\
\hline Setting & Institutional and community setting.
\end{tabular}

Source: Whittemore, R. \& Knafl, K., 2005, 'The integrative review: Updated methodology', Journal of Advanced Nursing 52(5), 546-553 
TABLE 2: Sources for formal search.

\begin{tabular}{lll}
\hline Databases (Platform) & Databases & Completed and current research \\
\hline EBSCOhost & Academic Search Premier & International journals on health science - primary studies. \\
& Source: Nursing and/or Academic & \\
& File Premia & - \\
CINAHL with full text & - \\
Healthsource Consumer Edition & - \\
Healthsource: Nursing and/or Academic Edition & - \\
MEDLINE (nursing and allied professions) & - \\
Africa-Wide: NiPAD & Scholarly articles in behavioural sciences in mental health. \\
& PsycINFO & International journals on health science - primary studies. \\
& Science Direct & International systematic reviews and clinical trials in health science. \\
Cochrane Library & Current and completed research projects in South Africa. \\
Nexus (NRF) & South African journals and publications - primary studies. Full text South African journals. \\
Sabinet Online: ISAP SAe Publication & Scholarly literature. \\
Google scholar & All references. \\
Manual search: References of primary studies &
\end{tabular}

- Written in English or translations thereof, including wellwritten English abstracts of any eligible primary study

- Relevant primary research studies from 2000 to 2010. Only literature and studies of this time period were used so as to ensure that the literature was recent.

\section{Exclusion criteria}

The exclusion criteria for this study were:

- Primary studies in foreign languages without English abstracts

- Conference abstracts

- Primary studies before 2000

- Primary studies after 2010

- Consumer/newspaper articles.

\section{Documentation of the search}

The articles were retrieved through the use of various databases, using the identified key words. Google and library loan were used in order to obtain all possible relevant articles. An experienced librarian at the North-West University assisted in a specific search strategy in Nexus (a national electronic database).

The study selection was initially conducted by screening titles and abstracts against the inclusion criteria so as to identify potentially relevant papers and availability of evidence. After reading the abstract, the studies that appeared to meet the inclusion criteria were. After this, the full papers of the abstracts identified as having possible relevance were then screened, as described by CRD (2009:13). Accurate record keeping was maintained throughout the process for audit purposes in order to enhance rigour. Seven studies were included for final critical appraisal. The number of studies that were identified, excluded and included are broken down in Figure 1.

\section{Step 3: Performing the critical appraisal}

In the systematic review, the sampling frame included all eligible studies. Critical appraisal of the selected studies for methodological quality and validity increases the complexity

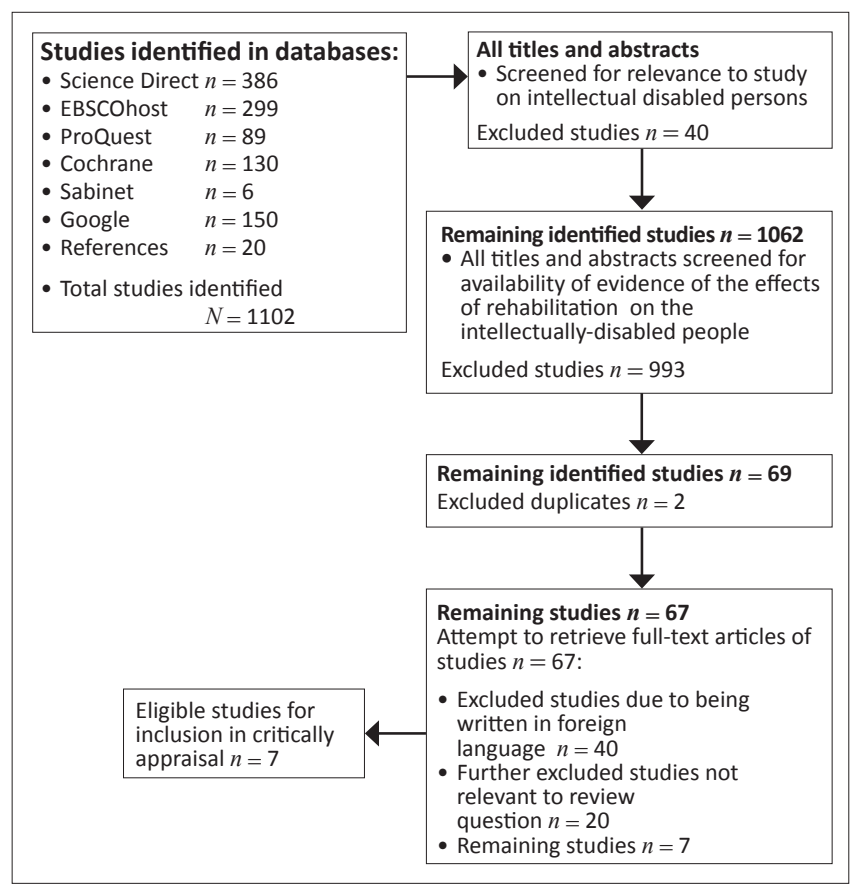

FIGURE 1: The realisation of the search strategy (sample).

whilst still enhancing the rigour of the systematic literature review. Quality evaluation for systematic literature reviews thus varies, depending on the sample frame (Whittemore \& Knafl 2005:549).

In this study, all relevant studies were appraised in terms of methodology and quality using the standardised checklists from the Critical Appraisal Skills Programme (CASP 2006). A record of all the appraised studies, instruments that have been used for appraisal, appraisal outcomes and motivation for decisions on inclusion and exclusion was kept for audit purposes. A second reviewer was asked to perform an independent appraisal of the selected studies for methodological quality and inclusion in or exclusion from the systematic literature review. Any conflict that occurred during appraisal was resolved by personal discussion between the researcher and the independent reviewer. After critical appraisal was conducted, a final list with relevant and 
rigorous studies was compiled. These studies were used for the next step, namely, data extraction.

The realisation of the entire search strategy to yield the studies for critical appraisal can be found in Figure 1.

\section{Step 4: Findings of evidence and summarising the evidence}

The summary of the evidence presents the cumulative information, data and quality of evidence for the most important outcomes; an explanation of data extraction and data synthesis; and a discussion and recommendations.

\section{Data extraction and data synthesis}

Data extraction elements (presented in Table 3) of each study involved the focus of the study, the main findings and other findings that were relevant to this systematic review. All data extracted were graded on the strength of their evidence supporting the conclusions or recommendation, according to the guidelines in the analysis manual of the American Dietetic Association Evidence (ADA 2008:62).

Data extraction of the relevant, selected and included studies was performed using data reduction and data display. Data reduction requires the determination of an overall classification system or subgrouping in order to manage data generated through diverse methodologies. It includes techniques for the extraction and coding of data from primary studies in order to simplify, abstract, focus and organise said data into a manageable framework for the comparison of issues, variables, sample characteristics and findings from the individual studies that are relevant to the review question. Data display involves the conversion of extracted data from individual primary studies into a display depicting assembled data from multiple primary studies on particular variables. The data display can be in the format of matrices, graphs, spreadsheets or charts (Whittemore \& Knafl 2005:550). In this study, all the relevant primary studies included for review were classified according to study design and type of evidence. The extracted data from this systematic review were coded in order to compare the themes and variables for display in table format. This is a formalised process for the collection of study characteristics. In addition, reporting of the characteristics of studies was an important component of the final review report, representing part of the review data trail that is claimed to be important for primary research (Evans \& Pearson 2001:114-115).

Data extracted from the systematic reviews included for synthesis of evidence are outlined in Table 3.

\section{Discussion}

Critical synthesis of the individual findings of the primary studies toward a conclusion entails data comparison, conclusion drawing and verification. Data comparison is a repetitive process involving examination of the data display in order to identify the patterns, themes and relationships of and between the variables. The drawing of conclusions and the verification thereof are on a higher level of abstraction than data comparison. Conclusions entail incorporation of the particulars into the general, as well as development of a conceptual model that is revised continually in order to include as much data as possible. Rigorous data synthesis reflects honesty, transparency and a thorough reflection and exploration is verified by continuous recordkeeping throughout the whole process (Whittemore \& Knafl 2005:551).

Verification with primary studies is required in order to enhance accuracy and confirmability. This is done in terms of discernment of the identified patterns, themes and relationships described in the final conclusion. Addressing conflicting evidence can be a considerable challenge and should be dealt with either by voting, comparing the frequency of significant positive findings against significant negative findings, exploration of confounding variables or motivation for the need of further research (Whittemore \& Knafl 2005:551). In this study, conflicting evidence was addressed by including the outcomes of rigorous and relevant studies in the conclusion statements, whether the studies contained conflicting evidence or not (refer to Table 3).

A systematic review was conducted for all published studies on the effects of rehabilitation on intellectually-disabled people. The relevant empirical evidence was also synthesised. The following findings and conclusions were identified from the systematic review:

- Classroom- and community-based skills training are effective when it comes to improving the functional ability of people with intellectual disabilities. It is thus important that the abovementioned training interventions are conducted on an ongoing basis in order to promote independence in terms of ADL of people with intellectual disabilities.

- After rehabilitation, marked improvement of skills is noted in younger intellectually-disabled people with higher IQs. In general, skills seem to increase over time for people with intellectual disabilities. Improved changes are noted in cognitive abilities and in the following main skill categories: self-care, communication and educational achievements. The residential situation is also said to affect several of the skills. Intellectuallydisabled people who live at home, with either relatives or foster parents, showed higher increases in almost every skill category, whilst those in hospitals and homes run by charities showed fewer increases. From this information, it would appear that the rehabilitation of intellectuallydisabled people is effective.

- People with mild to moderate intellectual disability benefit from occupational therapy and show improvement in terms of ADL. ADL performance is a factor for the development of autonomy and independence and consequently decreases the need for assistance in everyday life or in general. It can be concluded from this study that people with intellectual disabilities can benefit from occupational therapy interventions that are 
TABLE 3: Data extraction of systematic reviews included for synthesis of evidence.

\begin{tabular}{lll}
\hline Studies & Sample & Research question \\
\hline 1. Applegate et al. & $\begin{array}{l}\text { Single-subject study } \\
\text { design with one }\end{array}$ & $\begin{array}{l}\text { Does knowledge of results work } \\
\text { better at } 100 \% \text { or at a reduced } \\
\text { participant. }\end{array}$ \\
& $\begin{array}{l}\text { frequency for individuals with } \\
\text { intellectual disability, especially } \\
\text { in terms of their ability to learn } \\
\text { to tell time? }\end{array}$
\end{tabular}

2. Drysdale et al. 2008. An RCT (randomised Country: Northern $\quad$ control trial) with 40 Ireland

$\begin{array}{lll}\begin{array}{l}\text { 3. Hällgren \& Kottorp } \\ \text { 2005. Country: Australia }\end{array} & \begin{array}{l}\text { Quantitative single- } \\ \text { case design, using six } \\ \text { participants who } \\ \text { satisfied the inclusion } \\ \text { criteria. }\end{array} & \begin{array}{l}\text { What are the effects of an } \\ \text { occupational therapy } \\ \text { intervention program on ADL } \\ \text { ability and awareness of } \\ \text { disability in persons with } \\ \text { intellectual disabilities? }\end{array}\end{array}$

\section{Beadle-Brown et al. Cohort of 146 2002. Country: UK children. \\ Not specified}

'The results of the study generally indicate that incorporating knowledge of results into the learning strategy of an individual with intellectual disability facilitated the ability to tell time more accurately' (Applegate et al. 2008:32).

Is community living skills training effective in improving the functional ability of children with moderate learning disabilities?
Research outcome

\section{Results suggested that community} skills training was effective in improving the functional ability of people with intellectual disabilities.
The results indicated that performance in persons with mild to moderate intellectual disability improved in terms of AD after the intervention phase

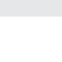

Results indicated that skills had improved in many areas between different assessment timeframes. Improvement was more noticeable for the children who had been youngest at the time.

\section{Findings}

The participants in the study demonstrated an increase in their performance ability to correctly identify the time on an analogue clock face.

Findings indicated that classroom-based training was as effective as that supplemented by community-based training.

'The outcome from this study supports previous fhe outcome from this study supports previous findings that community skills training can be effective in improving the functional ability of
people with intellectual disabilities' Drysdale people with intel
et al. 2008:247).

This study supports the findings of the pilot study of Kottorp et al. (2003). It is recommended that of Kottorp et al. (2003). It is recommended that
five sessions are sufficient to achieve a detectable five sessions are sufficient to achieve a detectab
clinical improvement in ADL performance. It is clinical improvement in ADL performance. It is
also recommended that clients be made aware also recommended that clients be made awar
of their disability, as awareness of disability of their disability, as awareness of disability
helps active participation in rehabilitation (Katz et al. 2002). ADL performance is "a factor for developing autonomy and independence with intellectual disability" (Kjellberg 2002; Ringsby 2002), consequently, decreasing the need for assistance in everyday life or in general. It is concluded from this study that persons with intellectual disabilities can benefit from with intellectual disabilities can benefit from occupational therapy interventions to improve ADL ability, even in the absence of any change in
their awareness of disability.'

'Findings indicate that skills seem to increase over time for people with intellectual disability in general (changes in cognitive ability and in general (changes in cognitive ability and for three main skill categories: self-care
skills, communication skills and educational skills, communication skills and educational
achievements)' (Beadle-Brown et al. 2002:20). achievements)' (Beadle-Brown et al. 2002:20).
The residential situation is said to affect several of the skills, it is stated that 'intellectual disabled people living at home, with relatives or foster parents showed higher increases on almost every skill category than those in hospitals and charityrun homes, for example' (Beadle-Brown et al. 2002:20). This finding could be explained by the effect of IQ and overall ability. Those children who were less able mentally and physically were those who were placed in hospitals or specialised homes, whilst those who were more able stayed at home with their parents for longer.

Bottom-line findings: 'The encouraging findings are that skills seem to increase over time for people with intellectual disabilities in general. These increases are greater at the younger ages and for the most parts for those of a higher 10 . The residential situation is also said to affect The residential situation is also said to affect
several of the skills. Intellectual disabled persons several of the skills. Intellectual disabled persons showed higher increases on almost every skill showed higher increases on almost every skill category than those in hospitals and (Beadle-Brown et al. 2002:12).

Findings indicated that all three participants improved in ADL process ability

Bottom-line findings: 'Results from this study indicate that an occupational therapy intervention programme, including restorative occupation and adaptive occupation, is effective in improving adaptive occupation, is effective in improving the ability of people with mental retardation to 2003:51).

occupation-based intervention that an occupational therapy programme result in enhancing intervention programme had a both awareness of disability and ADL ability for clients with ability for three people with mental retardation.

From this research it is stated that the significant increase in adaptive functioning amongst the intervention group children might have followed Intellectually-disabled children showed a significant improvement in the acquisition of adaptive behaviour after training. Improvement was noted in the intervention group in the areas of self-help general, self-help dressing and socialisation in addition to the areas of self-help eating, communication and locomotion. However, areas of occupation and

self-direction did not show a statistically significant increase in scores despite the

scores despite the
clinical improvements noted in these areas from factors and processes unknown. However, it
is known that parents of children with disabilities place importance on adaptive behaviour development.

Bottom-line findings: 'Investigation clearly showed additive efficacy of enhanced parental attitude in the acquisition of adaptive behavior amongst children with intellectual disability; the minimum additive efficacy achieved was $80 \%$ ' (Russell et al. 2004:383). 
TABLE 3 (Continues...:) Data extraction of systematic reviews included for synthesis of evidence.

\begin{tabular}{|c|c|c|c|c|}
\hline Studies & Sample & Research question & Research outcome & Findings \\
\hline \multirow[t]{2}{*}{$\begin{array}{l}\text { 7. Lloyd } 2007 . \\
\text { Country: Australia }\end{array}$} & \multirow{2}{*}{$\begin{array}{l}\text { Qualitative research } \\
\text { ethnographic method } \\
\text { supported by a } \\
\text { collaborative enquiry } \\
\text { approach to participative } \\
\text { action research. The } \\
\text { source population } \\
\text { involved gathering a } \\
\text { group of 18- to } 35 \text {-year- } \\
\text { old strangers from } \\
\text { amongst the general } \\
\text { public, in a mixed-gender } \\
\text { group, with same-gender } \\
\text { pairing of buddies. The } \\
\text { researcher became } \\
\text { totally embedded in } \\
\text { the community of } \\
\text { participants and assumed } \\
\text { the role of a tribal leader. }\end{array}$} & \multirow{2}{*}{ Not specified } & \multirow{2}{*}{$\begin{array}{l}\text { The results indicated that it was } \\
\text { possible to generate increased } \\
\text { well-being and confidence for more } \\
\text { independent living amongst people } \\
\text { living with the challenge of } \\
\text { intellectual disability. } \\
\text { Their ongoing wellbeing depends } \\
\text { equally on community settings of } \\
\text { shared affirming energy and daily } \\
\text { living feedback, mirroring and } \\
\text { support. Therefore, the open valuing } \\
\text { approach of psychosocial } \\
\text { rehabilitation creates open and } \\
\text { ongoing mutual support in an } \\
\text { equitable and non-labelling or } \\
\text { patronising way, and can also create } \\
\text { much more cost-effective forms of } \\
\text { CBR as compared to the current } \\
\text { medical models (e.g. of allocating } \\
\text { one facilitator to } 60 \text { participants } \\
\text { over two years, with an average time } \\
\text { commitment of two } \\
\text { days a week). }\end{array}$} & $\begin{array}{l}\text { People living with intellectual disability experience } \\
\text { improved increased quality of life and self- } \\
\text { determining sense of self when they are included } \\
\text { in mixed, open urban tribes or communities of } \\
\text { belonging. Being with other participants also } \\
\text { provides shared testimonies of experience, which } \\
\text { give each other encouragement and stimulation, } \\
\text { generating motivation and strengthened intention } \\
\text { for life. People reported feeling well, showed } \\
\text { evidence of finding more energy for life and began } \\
\text { pursuing more diverse activities and creativity. }\end{array}$ \\
\hline & & & & $\begin{array}{l}\text { Bottom-line findings: 'The bottom line is that } \\
\text { this process of person-valuing approach to } \\
\text { psychosocial rehabilitation showed to produce } \\
\text { efficacious results in the lives of all participants. } \\
\text { An interactive symbolic environments elicits } \\
\text { important information about practical ways } \\
\text { to assist the daily lives of peoples living with } \\
\text { psychosocial challenges in an environment if } \\
\text { sharing and being with other participants revealed } \\
\text { that intellectually-disabled people feel better } \\
\text { about themselves and express more confidence } \\
\text { and independence, especially when they are } \\
\text { in a community of belonging where respectful, } \\
\text { equitable relationships of safety and trust are } \\
\text { established. The participants were assisted to help } \\
\text { themselves and each other in terms of recovery, } \\
\text { growth and development when they are enabled } \\
\text { to come together in a vulnerable, safe and trusting } \\
\text { environment of sharing and caring. Successful } \\
\text { psychosocial rehabilitation depends on people's } \\
\text { motivation for recovery, growth and development, } \\
\text { and this happens best in communities of } \\
\text { belonging where there is shared affirming energy } \\
\text { and daily living feedback and support, and not } \\
\text { in isolated group homes or through patronising } \\
\text { professional service delivery that pathologies its } \\
\text { recipients. This type of rehabilitation provides } \\
\text { cheaper bottom-line costs, that is it creates a } \\
\text { much more cost-effective CBR. Therefore, people } \\
\text { living with psychosocial challenges require clinical } \\
\text { assistance to get their lives in balance' (Lloyd } \\
2007: 99 \text { ). }\end{array}$ \\
\hline
\end{tabular}

designed to improve their ADL ability. It can thus also be predicted that, with collaboration between occupational therapists, other mental health care workers and nurses, rehabilitation of intellectually-disabled people will be effective.

- In support of the above paragraph, an occupational therapy intervention programme which includes both restorative and adaptive occupation is effective with regard to improving the ability of intellectually-disabled people to carry out ADL both efficiently and safely. In this case, further research is also needed in order to determine whether such a programme also leads to an improvement in ADL, motor ability and awareness of their disability.

- Investigations also showed clearly the additive efficacy of enhanced parental attitude with regard to the acquisition of adaptive behaviour amongst children with intellectual disabilities. The minimum additive efficacy achieved was $80 \%$, with intellectually-disabled children showing a significant improvement in the acquisition of adaptive behaviour after training. The intervention group showed improvement in the areas of self-help, both general and with regard to dressing and socialisation, as well as in the areas of self-help eating, communication and movement.

- Prior knowledge of results during the process of rehabilitation gives guidance for future performance and the knowledge of results also provides the intellectuallydisabled person with information needed to change their performance before the next performance occurs. The findings indicated that intellectually-disabled persons who received greater amounts of feedback during skills acquisition improved their performance and obtained higher scores during task performance. The results, therefore, are a general indication that incorporating knowledge of results into the learning strategy for a person with an intellectual disability facilitates the ability, for example, to tell time more accurately.

- The bottom-line is that the process of the person-valuing approach to psychosocial rehabilitation produces highly effective results in the lives of the participants. Interactive symbolic environments elicit important information regarding practical ways of assisting in the daily lives of people living with psychosocial challenges in an environment of sharing and being with other participants. It furthermore reveals that intellectually-disabled people gain a greater sense of well-being and show more confidence and independence, especially 'when they are in a community of belonging where respectful, equitable relationships of safety and trust are established' (Lloyd 2007:100). Successful psychosocial rehabilitation is dependent on the person's desire for recovery, growth and development, which happens best in communities where there is a shared energy with regard to affirmation, daily living feedback and support, in contrast with isolated group homes or patronising professional service delivery that nauseates its recipients. This type of rehabilitation provides cheaper bottom-line costs; in other words, it creates much more cost-effective CBR. People living with psychosocial challenges thus require clinical assistance in order to obtain balance in their lives. For example, these people need to be assisted to help themselves in order 
to become independent individuals. In this case, nurses of all categories, that is, professional nurses, enrolled nurses and assistant nurses, need to be trained regarding how to assist people with intellectual disabilities in their endeavour to become independent individuals.

\section{Limitations of the study}

This study used only electronic databases subscribed to by North-West University, which is a limitation because other universities might have access to different databases. However, this limitation was overcome by the use of multiple sources to obtain published studies, for example, electronic databases and manual search.

- This systematic review was conducted on studies presenting mostly with medium- and high-quality ratings and a mix of class A (randomised control trials), B (cohort studies) and C (qualitative studies) evidence. Limited generalisation in this context may be as a result of class $\mathrm{C}$ /single-case study designs having too small a number of participants to allow generalisation to a larger population. Another reason for limited generalisation was the limited improvement in skills, which may be attributed to the fact that other intellectually-disabled people 'have a diminished capacity to understand the underlying abstract meaning of questions asked and causal relationships. [This] may impact on their ability to think and reflect upon ADL performance' (Hällgren \& Kottorp 2005:355).

The major limitation of this study was the amount of variability and fluctuation in the data, even though all participants showed differences before and after the intervention programme. With this variability in mind, all results should be viewed with caution. Because other studies did not include additional control groups, the presence or size of such effects are not measurable.

\section{Recommendations}

Many intellectually-disabled people experience difficulties with regard to obtaining appropriate rehabilitation intervention and continued assistance. Findings amongst people with disabilities highlight the fact that the healthcare and welfare systems should create a coordinated system for the improvement of rehabilitation services amongst intellectually-disabled people. Because intellectuallydisabled people have multiple healthcare needs, healthcare policies should reorganise the healthcare system to make it respond appropriately to their needs.

There is some small-scale evidence which suggests that various psychosocial interventions may be feasible for people with mild intellectual disabilities. Research is, therefore, still needed, as research evidence related to the effects of psychosocial intervention on the intellectually-disabled person is sparse.

The following recommendations are made specifically with regard to nursing, as intellectually-disabled people have multiple healthcare needs. Healthcare policy should thus reorient the healthcare system to respond appropriately to these patients' needs.

\section{Recommendations for nursing practice}

There is a real need for rigorous practice-based evidence to reinforce the increasing range of treatment options for this group of service users. For this reason, rehabilitation training should be incorporated into nursing practice. This will enable nurses to equip intellectually-disabled people with skills to acquire basic life skills and to manage ADL. Since nurses form part of the multidisciplinary team, it is important that occupational therapists collaborate with the nurses in order to ensure that the rehabilitation of intellectually-disabled people is done effectively and on an ongoing basis.

\section{Recommendations for nursing education}

Nurses of all categories, namely, professional nurses, enrolled nurses and assistant nurses, need to be educated, trained and equipped with rehabilitation skills and knowledge in order to assist people with intellectual disabilities within institutional/community settings, with the aim of promoting their quality of life.

\section{Recommendations for nursing research}

There is a real dearth of clinical research evidence concerning the effects of rehabilitation on intellectually-disabled people. The knowledge gained will add to the research knowledge base. Further research is still needed and should focus on the efficacy of specific rehabilitation service types provided to people with intellectual disabilities in South Africa.

\section{Conclusion}

Persons with mild to moderate intellectual disabilities improved in terms of their activities of daily living. On the other hand, persons with intellectual disabilities can benefit from occupational therapy interventions in order to improve their ADL ability, even in the absence of any change in their awareness of disability. It is thus important that occupational therapists and other mental health care workers collaborate with nurses in order to ensure that the rehabilitation of intellectually-disabled people is effective.

\section{Acknowledgements}

The authors would like to acknowledge Dr Vicki Koen for assistance with and final editing of this article.

\section{Competing interests}

The authors declare that they have no financial or personal relationship(s) which may have inappropriately influenced them in writing this article.

\section{Authors' contributions}

E.J.S. (North-West University) was a Master's degree student who completed a mini-dissertation in partial 
fulfilment of the requirements for the degree Magister Curationis in Psychiatric Nursing Science. B.S. (NorthWest University) was his supervisor and D.K. (North-West University) his co-supervisor. E.J.S. was responsible for the whole research process and B.S. and D.K. gave feedback, structure and guidance during this process, in addition to checking the work for final submission for examination as well as publication.

\section{References}

American Dietetic Association (ADA), 2005, Scientific affairs \& research: ADA evidence analysis manual, Scientific Affairs and Research, American Dietetic Association, Chicago, IL.

American Dietetic Association (ADA), 2008, Evidence analysis manual: steps in the $A D A$ evidence analysis process, Scientific Affairs and Research, American Dietetic Association, Chicago IL.

Applegate, S.L., Rice, M.S., Stein, F. \& Maitra, K.K., 2008, 'Knowledge of results and learning to tell the time in an adult male with an intellectual disability: A single-
subject research design', Occupational Therapy International 15(1), 32-44. http:// subject research design, Occup
dx.doi.org/10.1002/oti.242

Badr, E., 2007, 'Making use of systematic reviews', Sudanese Journal of Public Health 2(2), 79-80.

Beadle-Brown, J., Murphy, G., Wing, L., Gould, J., Shah, A. \& Holmes, N., 2002 'Changes in social impairment for people with intellectual disabilities: a follow-up of the Camberwell Cohort', Journal of Autism and Developmental Disorders 32(3), 195-206. http://dx.doi.org/10.1023/A:1015401814041

Burns, J.K., 2008, 'Implementation of the Mental Health Care Act (2002) at district hospitals in South Africa: Translating principles into practice', South African Medical Journal 98(1), 46-49.

Centre for Reviews and Dissemination, 2009, Systematic reviews: CRD's guidance for undertaking reviews in health care, University of York, York.

Critical Appraisal Skills Programme (CASP), 2006, Evidence based health care, viewed 24 December 2008, from http://www.sph.nhs.uk/sph-files/casp-appraisaltools/?searchterm=CASP\%20 tools [updated link to equivalent file viewed 17 June 2014, from http://www.caspinternational.org/mod product/uploads/ CASP_Systematic_Review\%20_Checklist_14.10.10.pdf]

Chappell, P. \& Johannsmeier, C., 2009, 'The impact of community based rehabilitation as implemented by the community rehabilitation facilitators on people with disabilities, their families and communities within South Africa', Disability and Rehabilitation 31(1), 7-13. http://dx.doi.org/10.1080/09638280802280429

Department of Health (DoH), 2000, National rehabilitation policy, DoH, Pretoria.

Drysdale, J., Casey, J. \& Porter-Armstrong, A., 2008, 'Effectiveness of training Scandinavian Journal of Occupational Therapy 15(4), 247-255. http://dx.doi. org/10.1080/11038120802456136
Evans, D. \& Pearson, A., 2001, 'Systematic reviews of qualitative research', Clinical Effectiveness in Nursing 5(3), http://dx.doi.org/10.1054/cein.2001.0219 111-117.

Hällgren, M. \& Kottorp, A., 2005, 'Effects of occupational therapy intervention on activities of daily living and awareness of disability in persons with intellectual disabilities', Australian Occupational Therapy Journal 52(4), 350-359. http:// dx.doi.org/10.1111/j.1440-1630.2005.00523.x

Katz, N., Fleming, J., Keren, N., Lightbody, S. \& Hartman-Maeir, A., 2002, 'Unawareness and/or denial of disability: Implications for occupational therapy intervention', Canadian Journal of Occupational Therapy 69(5), 281-292. http://dx.doi. org/10.1177/000841740206900504

Kjellberg, A., 2002, Participation - ideology and everyday life, Studies from the Swedish Institute for Disability Research (No. 6), University of Linköping, Sweden.

Kottorp, A., Hällgren, M., Bernspång, B. \& Fisher, A.G., 2003, 'Client-centred occupational therapy for persons with mental retardation: Implementation of an intervention programme in activities of daily living tasks', Scandinavian Journal of Occupationa Therapy 10(2), 51-60. http://dx.doi.org/10.1080/11038120310009416

Legere, L., 2007, 'The importance of rehabilitation', Psychiatric Rehabilitation Journa 30(3), 227-229. http://dx.doi.org/10.2975/30.3.2007.227.229

Lin, J-D., Yen, C-F., Loh, C-H., Li, C-W. \& Wu, J-L., 2006, 'Rehabilitation service utilization and determinants among people with intellectual disability: Preliminary findings in Taiwan', Disability and Rehabilitation 28(23), 1499-1506. http://dx.doi. in Taiwan, Disability and Rehabilit

Lloyd, R., 2007, 'Modeling community-based, self-help mental health rehabilitation reform', Australasian Psychiatry 15(Suppl 1), S99-103. http://dx.doi. reform', Australasian Psychiatry
org/10.1080/10398560701701296

Martin, R., 2006, 'A real life - a real community: The empowerment and full participation of people with an intellectual disability in their community' Journal of Intellectual \& Developmental Disability 31(2), 125-127. http://dx.doi. org/10.1080/13668250600681511

Oh, K, Kim, J.H., Rosenthal, D.A. \& Lui, J.W., 2005, 'Vocational rehabilitation in South Korea: Historical development, present status, and future direction', Journal of Rehabilitation 71(1), 49-55.

Ringsby, J.B., 2002, The arenas of everyday life. About the daily and social lives of people with intellectual disabilities, Department of Social Work, University of Gothenburg, Sweden.

Russell, P.S.S., John, J.K., Lakshmanan, J., Russell, S. \& Lakshmidevi, K.M., 2004, 'Family intervention and acquisition of adaptive behaviour among intellectually disabled intervention and acquisition of adaptive behaviour amo
children', Journal of Learning Disabilities 8(4), 383-395.

South Africa, 1973, Mental Health Act 18 of 1973, Government Printer, Pretoria.

South Africa, 2002, Mental Health Act 17 of 2002, Government Printer, Pretoria.

Thompson, J.R., McGrew, K.S. \& Bruininks, R.H., 2002, 'Pieces of the puzzle: Measuring the personal competence and support needs of persons with intellectual disabilities', Peabody Journal of Education 77(2), 23-39. http://dx.doi. org/10.1207/S15327930PJE7702_4

Whittemore, R. \& Knafl, K., 2005, 'The integrative review: Updated methodology', Journal of Advanced Nursing 52(5), 546-553. http://dx.doi.org/10.1111/j.13652648.2005.03621.x 